WHAT'S

HAPPENING

\title{
Innovations in Care Delivery
}

\section{From the Editor}

\author{
Kevin A. Kerber, MD, MS, and Brian C. Callaghan, MD, MS
}

Innovations in Care Delivery (IICD) highlights articles that feature advances in care delivery in our Editor's Blog, Editor's Top Five Recommended Reading, and Latest Articles sections. Interviews with leaders in the field of health services research are included periodically.

\section{Editor's Blog}

Recent IICD blogs have discussed issues relating to the COVID-19 pandemic including sprints and marathons: lessons from superstorm Sandy to COVID-19, the aging neurologist in the time of COVID-19, and stroke assessments in the COVID-19 era. Our goal is to highlight health services research articles published in Neurology ${ }^{\circledR}$ or Neurology Clinical Practice $^{\circledR}$ and to give opinions by experts in the field.

\section{Editor's Top Five Recommended Reading and Latest Articles Sections}

Check out our collection of Neurology's articles related to Innovations in Care Delivery NPub.org/innovations.

In a commentary in Neurology, Brownles et al. ${ }^{1}$ discussed issues related to treating multiple sclerosis during the COVID-19 pandemic. The authors addressed delivery of care using telemedicine and specifically a previous study on the accuracy of measures of disability using telemedicine compared with the office setting. They also mentioned other ways to maintain low exposure care including home delivery of medications, delaying follow-up MRI scans and routine laboratory monitoring, oral corticosteroids, and less frequent dosing of infusions.

In addition, check out the article by French et al. ${ }^{2}$ and a large coalition of multinational specialists to develop consensus recommendations on care for people with epilepsy while avoiding visits to medical facilities during the novel coronavirus pandemic. The consensus recommendations include focusing on home-based care (e.g., emphasize most seizures last less than 2-3 minutes and do not require emergency medical services), minimizing of the risk of seizure exacerbation through adherence and ensuring a regular supply of medication, and postponing neuroimaging and EEG unless required to address urgent diagnostic or therapeutic issues. The coalition also provides links to helpful information for patients and providers.

\section{References}

1. Brownlee W, Bourdette D, Broadley S, et al. Treating multiple sclerosis and neuromyelitis optica spectrum disorder during the COVID-19 pandemic. Neurology 2020;94:949-952

2. French J, Brodie M, Caraballo R, et al. Keeping people with epilepsy safe during the COVID-19 pandemic. Neurology 2020;94: 1032-1037.
MORE ONLINE

COVID-19 Resources

For the latest articles, invited commentaries, and blogs from physicians around the world NPub.org/COVID19 


\section{Neurology}

\section{What's happening in Innovations in Care Delivery \\ Neurology 2020;95;259 \\ DOI 10.1212/WNL.0000000000010128}

This information is current as of August 10, 2020

\section{Updated Information \&} Services

References

Permissions \& Licensing

Reprints including high resolution figures, can be found at: http://n.neurology.org/content/95/6/259.full

This article cites 2 articles, 2 of which you can access for free at: http://n.neurology.org/content/95/6/259.full\#ref-list-1

Information about reproducing this article in parts (figures,tables) or in its entirety can be found online at:

http://www.neurology.org/about/about_the_journal\#permissions

Information about ordering reprints can be found online:

http://n.neurology.org/subscribers/advertise

Neurology ${ }^{\circledR}$ is the official journal of the American Academy of Neurology. Published continuously since 1951, it is now a weekly with 48 issues per year. Copyright @ 2020 American Academy of Neurology. All rights reserved. Print ISSN: 0028-3878. Online ISSN: 1526-632X.

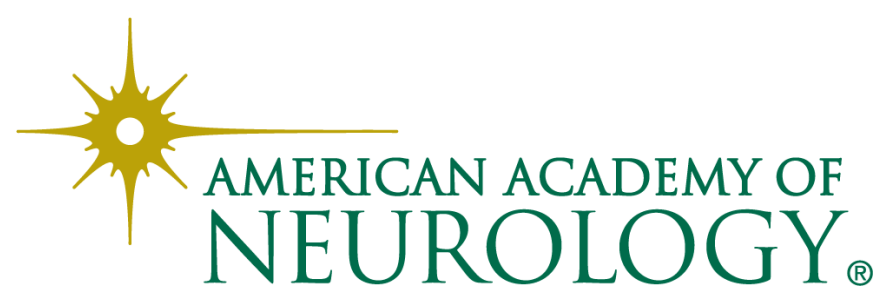

